\title{
Exploring the Typology of Challenges and Strategies in Translating Culture-Bound Items for Professional Purposes
}

\author{
Maha M. Aldhahi ${ }^{1}$, María Fernández-Parra ${ }^{1} \&$ Lloyd H. Davies ${ }^{1}$ \\ ${ }^{1}$ Dept. of Modern Languages, Translation and Interpreting, Swansea University, UK \\ Correspondence: Maha M. Aldhahi, Dept. of Modern Languages, Translation and Interpreting, Swansea \\ University, Singleton Park, Swansea, UK. E-mail: Maha.Aldhahi@gmail.com
}

\author{
Received: November 28, 2017 Accepted: December 29, 2017 Online Published: February 4, 2018 \\ doi:10.5539/ijel.v8n3p1 URL: http://doi.org/10.5539/ijel.v8n3p1
}

\begin{abstract}
The translation of culture-bound expressions such as idioms, proverbs and similes can be a challenge even for professional translators who are expected to have an excellent command of the languages they work with, at least theoretically. Challenges arise when either the image or the meaning of the source language expression does not exist in the target language. For instance, the Arabic simile كمسمار جحا translates literally as "like Juha's nail" (image). However, a more suitable translation into English would in fact be along the lines of "no more than a vacuous excuse" (meaning). Therefore, in this paper, the author aims to establish, by conducting a survey of Arab professionals, the extent to which these expressions pose a challenge when translating between English and Arabic. In this survey, translators are also asked to translate selected culture-bound expressions and comment on them. The initial results will show that the translation of culture-bound expressions can indeed cause significant challenges for professional translators and that these challenges can be grouped into five categories on the basis of image and meaning. Suggestions regarding procedures will be made to overcome these cultural challenges by category. Overall, the results will suggest that there is a pressing need to increase the cultural component in translator training programmes.
\end{abstract}

Keywords: cross-cultural communication, culture-bound expressions, idiom, proverb, simile, translator training

\section{Culture-Bound Items}

Despite current developments in translation theories and practices, culture-bound items (CBIs) remain a significant problem area for translators (Baker, 2011, p. 3). Translation of CBIs such as idioms, proverbs, metaphors and similes can be a challenge even for professional translators, who are expected to have an excellent command of the languages they work with, at least theoretically. Challenges arise when either the image or the meaning of the source language expression does not exist in the target language. For instance, the Arabic simile كمسمار جحا translates literally as "like Juha's nail" (image). However, a more suitable translation into English would in fact be along the lines of "no more than a vacuous excuse" (meaning). This paper aims to explore the challenge CBIs pose when translating between English and Arabic based on the image and meaning of these expressions. Thus, this paper establishes the extent to which these expressions pose a challenge when translating between English and Arabic based on direct and non-direct translation equivalents and puts forward procedures to overcome these cultural challenges. To translate such expressions, the translator needs an effective dynamic equivalent rather than translating word-for-word, since the aim is to have an impact equivalent to that of the L1 expression (Newmark, 1991, p. 26). In this light, it is highly important to develop the research into the translation of CBIs, which, in turn, will help professional translators translate more effectively.

\section{The Processing and Comprehension of English CBIs and Arabic CBIs}

Although idioms and other types of CBIs are more common in informal discourse, native speakers typically acquire a great number of CBIs. Therefore translators, who are supposed to become equally proficient in their L2 as in their L1, should comprehend the CBIs in their L2 as well as in their L1. Recent studies on acquisition of L2 (e.g., Masrai \& Milton, 2015) have shed light on another crucial factor in the translation of L2 texts, that is, words with direct translation equivalents in the L1; for example, the words test, patient, crazy, and salt compared to words with non-direct translation equivalents such as review, at, charity and snow. As Jiang claims, synonyms in one language may have a single word equivalent in another language (2000, 2002, 2004). Another problem arises with words such as "صحيفة / جريدة" in Arabic, which do not have an equivalent in English. Although 
"newspaper" might be used to refer to the same thing, it is a combination of two words, each of which has an equivalent in Arabic; "أخبار" the back translation of which is "news", and "أوراق", the back translation of which is "paper".

Masrai and Milton state that "learners appear to have difficulty learning words with a non-direct translation equivalent, although, in fact, they are at the same or higher word frequency level in English compared to the words with a direct translation equivalent" $(2015$, p. 4$)$. In other words, Masrai and Milton's conclusion seems to suggest that words with direct translation equivalent in L1, even with a lower frequency level, are learned more readily than higher word frequency levels with non-direct translation equivalents in the L1. They state that learners, arguably, translators "tend to lean heavily on word translation type in the first place and word frequency comes second" (Masrai \& Milton, 2015, p. 4). Since CBIs are not as frequently used as vocabulary items, the processes and comprehension of CBIs can be investigated by observing the direct and non-direct translation equivalents. This is in line with Alhaysony's study (2017, p. 78), where she found that learners tend to rely on idiomatic expressions that have an equivalent in their SL. Al-Faifi (2000, p. 295) suggested that translators "must acquire cultural competence [in the SL] to be able to construct similar cultural experiences" in the TL. Therefore, as an initial stage, in the same way learners do, translators need to master CBIs in their SL in order to be able to process them equally proficiently in the TL.

In this regard, the literal first hypothesis (Bobrow \& Bell, 1973) is one of many approaches in the processing and comprehension of idiomatic expressions that can be used in this study, as all CBIs can be considered idiomatic to some extent. This hypothesis suggests that the literal meaning was given first but then the learner realized that the literal meaning was not acceptable and he turned to figurative meaning. In this respect, Bobrow and Bell propose that literal interpretation is always comprehended more quickly than figurative meaning, which can explain the difficulty of processing and comprehension for learners. Employing word-for-word (i.e., linking L2 words with their direct translations in the L1) translation can be a great challenge for translators since some words are used metaphorically in expressions such as golf widow, as strong as an ox. Translating these CBIs with their direct translation will lead to misunderstandings, since, for example, the figurative meaning of golf widow as a whole is "مهملة من زوجها", the back translation "neglected by her husband" is different from the meaning of the individual component words.

On the other hand, expressions such as as strong as an ox have negative connotations in Arabic, i.e., you may be strong as an ox but you are also probably stupid, compared to English, i.e., you are as strong as an ox and this is considered as positive in the L2. Thus, the challenge in this category is that both Arabic and English expressions are figurative expressions and are based on the figurative first hypothesis' (Gibbs, 1980): native speakers recognize first figurative meaning then the literal meaning. Since this expression exists in the L1 Language, translators think that they recognize the figurative expression, which leads to mistranslation.

This means that direct translation equivalent is not always a good choice for translators as neither single words as in the example "golf widow" nor the figurative expression "as strong as an ox" give the right meaning. In general, it is not a good idea to depend excessively on word-for-word translation, frequency or formality. Translators need to increase cultural awareness and comprehend the cultural meaning behind the words. But expressions such as play with fire (En.; Ar.) and apple of her father's eye (En.) joy of her father eye (Ar.) should be easy according to these hypotheses. This is because these expressions are used in both cultures with the same connotations.

Thus, the present study identifies all types of expression that have direct and non-direct translation equivalents and gives more attention to those expressions with direct translation equivalents regarding image but have different connotations; here they are referred to as same/similar image — different meaning. This category (no. 4 in this paper) was mentioned by Baker (2011) but it does not seem to have received much attention in translation studies. The nature of this Category 4 is highly important since the translators may think that they know the figurative meaning, as it has the same or similar meaning in their SL (direct translation) and could end up translating it with a wrong meaning. A mistake in Category 4 can not only lead to misunderstanding but also to crossing translation boundaries. For instance, the English speaker perceived the similes such as you're my/mommy's little monkey, or strong as an ox and tall as a giraffe positively as a compliment, but the same image use was perceived negatively by Arabic speakers.

The definition of CBI is based on Wray's definition of formulaic sequence as "a sequence, continuous or discontinuous, of words or other meaning elements, which is, or appears to be prefabricated: that is stored and retrieved whole from the memory at the time of use, rather than being subject to generation or analysis by the language grammar" (Wray, 2002, p. 9). Thus, CBIs are a subset of formulaic expressions that have a strong 
cultural component. They can range from single words, e.g., bobby, hooligan, Beefeater, etc, to multi-word expressions, e.g., cream tea, trick or treat, as the crow flies, like a bull in a china shop, etc. The cultural component of CBIs could pose problems in translation and might require a special effort from translators to render them appropriately into the target language and culture.

Influential studies on formulaic language (e.g., Wray, 2002) state that L2 learners can improve the overall impression of their L2 production by using formulaic language (and therefore CBIs) which leads to more native-like translation. As noted by Ellis and Sinclair (1996; p. 234), "the attainment of fluency, in both native and foreign languages, involves the acquisition of memorized sequences of language." Thus, CBIs can be processed faster than vocabulary items (e.g., Ortony et al., 1978; Wray, 2002). This is supported by the simultaneous processing hypothesis (Swinney \& Cutler, 1979) according to which vocabulary size is subject to a different analysis such as lexical, syntactical and semantic. CBIs are seen as one single unit and are therefore not subject to the previous analysis. As a consequence, CBIs have an advantage in terms of processing speed (Karlsson, 2013).

Thus, in this study, the researchers suggest that translators need to develop a higher sensitivity to the meaning and connotations of individual words, not only by learning the most frequent words and applying word-for-word translation but also to consider formulaic language; mainly the CBIs that have deeper meanings, especially from the viewpoint of culture. More importantly, by viewing these hypotheses, it seems that training translation programmes in Arabic countries have underestimated the important strategies in processing and comprehending cultural content.

\section{Translation Strategies}

This study draws attention to Pym's (2017) point of view of looking at translation solutions. He is on firm ground in addressing diverse procedures, strategies, techniques and so on, under one label, translation solutions. By using this term, the translation process becomes a process of problem-solving which can indeed lead to more creative ways of finding new solutions and to think "outside the box". This can be beneficial especially if trainee translators limit themselves to the normal solution types which occur in the cognitive process of memorising all the differences between these overlapping typologies (see Table 1). Pym (2017) believes that different typologies can be misleading especially for trainee translators. He explains that they should be aware of the different options available to them but not limit themselves to these options. He provides a table for students in translation programmes outlining eight typology of solutions for translating different types of text which, he believes, can minimize any discrepancies between what he terms translation strategies, procedures and technique. This study discusses the possible solutions for translating CBIs with different levels of challenges.

Table 1. A typology of translation solution types for many languages (cf. Pym 2016, p. 220)

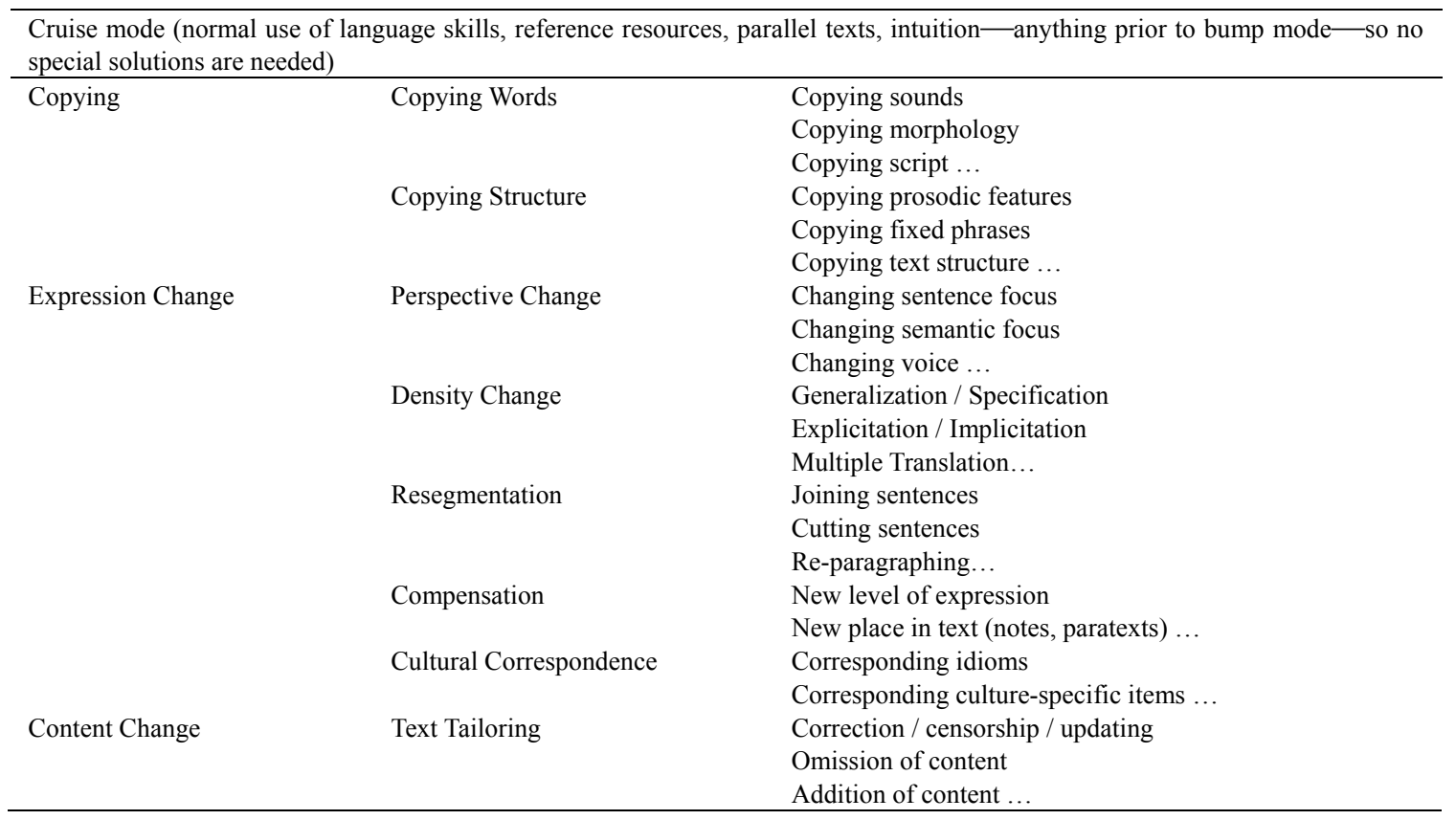


Table 1 shows a list of ways to solve problems in translation which Pym (2017) refers to as "cruise mode". With this list, the translator can use any combination of solutions and can be creative and invite new solutions. Following sections 5.1, to 5.5 there will be a discussion of each category and the best way to overcome these cultural challenges.

\section{Methodology}

The methodology used in this paper is quantitative and qualitative. A list of CBIs types was identified from Fernández-Parra's list of formulaic expressions (2014, p. 42) since she established a new classification based on semantic, syntactic and pragmatic criteria. From her list, those expressions without obvious cultural components were eliminated. Aldhahi et al. (2016) found that Arabic professional translators made a number of errors in translating CBIs and in providing the procedures used. From these errors and from the literature review, the types of challenges were grouped into five categories (see Section 5). The vast majority of errors discovered were in the translation of the CBIs as follows (cf. Aldhahi et al., 2016):

Third language: where the target text reads like a "foreign" language and it "sounded wrong" (Duff, 1981, p. xi). 2.

Opposite meanings (Baker, 2011, p. 69) where both cultures have the same image but they perceive it differently as one culture uses the image for a negative purpose while the other uses it for a positive purpose.

The classifying of common difficulties encountered in the translation of CBIs is given below.

\section{Collection and Classification of CBIs}

The researchers selected, over a period of nine months, those expressions with a variety of associated cultural content from different sources such as films, TV programmes, websites, dictionaries, and books. The data collected consists of 1,100 CBIs, i.e., 550 English CBIs (ECBIs) and about 550 Arabic CBIs (ACBIs). The quotes, phrasal verbs, and collocations (about $90 \mathrm{CBIs}$ ) were eliminated in an initial analysis since their cultural influence was not as clear as other types of CBIs. The final set of CBIs amounted to 774 expressions ( $50 \%$ in each language) and is illustrated in the following Table.

Table 2. Total number of expressions

\begin{tabular}{|c|c|c|c|c|}
\hline CBI types & $\mathbf{N}$ & ECBIs & ACBIs & Example \\
\hline $\begin{array}{l}\text { Idioms and idiomatic } \\
\text { expressions }\end{array}$ & 250 & 125 & 125 & Talk for England \\
\hline Proverbs & 240 & 120 & 120 & Beware of the Greeks bearing gifts \\
\hline Similes & 122 & 61 & 61 & Like a bull in a china shop \\
\hline Collocations & 20 & 10 & 10 & Black tea \\
\hline Commandments & 20 & 10 & 10 & $\begin{array}{l}\text { "I am the LORD your God, who brought you out of the land of Egypt," } \\
\text { out of the house of bondage. You shall have no other gods before me." }\end{array}$ \\
\hline Common sayings & 102 & 51 & 51 & Christmas comes but once a year \\
\hline Prayers & 10 & 5 & 5 & Our Father who art in Heaven \\
\hline Social formulae & 10 & 5 & 5 & Nice to meet you \\
\hline Total & 774 & 387 & 387 & - \\
\hline
\end{tabular}

As shown in Table 2, the highest numbers of expressions were idioms, proverbs and similes. Thus, in this study, focus was placed on these types of CBI but the findings may well be applied to other categories of CBIs. Also, those expressions selected are divided into the five classifications (cf. see Table 3) based on the similarities and differences between the image and meaning of the expressions.

Based on a literature review (cf. Aldhahi, unpublished thesis), there were different classifications of idioms and idiomatic expressions on the similarities and differences between the expression and the equivalent. For example, Gläser (1984) established three groups of equivalences between idioms in L1 (English) and L2 (German):

1) "Complete equivalence" (close correspondence), e.g. the English expression, all roads lead to Rome, corresponds to the German expression Alle Wege führen nach Rom, and also in Arabic كل الطرق تؤدي الى روما These idiomatic expressions use the same structure and refer to the same meaning.

2) "Partial equivalence", e.g., lame duck corresponds to the German lahme Ente which refers to human agents only, while the English expression refers to human agents and to collective entities such as an enterprise. 
3) "Zero equivalence", e.g., to take (holy) orders can be translated into German as die heiligen Weihen empfangen, with the literal meaning "receive holy ordination" (which is quite close to the English); in den geistichen Stand eintreten, the back translation means "enter into the spiritual state/condition".

Gläser uses equivalence for the use of image only but underestimated other equivalents with a different image use. This could be very challenging for translators if they are limited to equivalence in images used because some expressions from different cultures have exactly the same image but with different connotations such as strong as an ox.

By contrast, Awwad (1990) considers the equivalents with different images and proposes four classifications of English idioms and their Arabic equivalent by means of the following categories:

1) Expressions and functions correspond in both languages, e.g., play with fire corresponds to the Arabic expression (يلعب بالنار), the back translation being "play with fire".

2) Functions correspond in both languages but expressions are completely different, e.g., waste one's breath corresponds to the Arabic expression (يضيح وقته), the back translation being "waste one's time".

3) Functions correspond but expressions differ slightly, e.g., to hold the reins corresponds to Arabic expression (يمسك زمام الأمور), with the back translation being "holding the reins of things".

4) Both expressions and functions differ and are language-specific, e.g., lip service corresponds to the Arabic expression (مجرد كلام), the back translation being "no more than talking".

Awwad's work covers many aspects of equivalence compared to Gläser's categories; however, the only category left out was the expression that used the same image and has a different meaning. Baker's classification (2011, pp. 71-75) identifies four main difficulties in arranging idioms in the following categories:

1) An idiom or fixed expression may have no equivalent in the target language (TL), e.g., in some culture-specific items such as Merry Christmas.

2) An idiom or fixed expression may have a similar counterpart in the TL, but its context of use may be different; the two expressions may have different connotations. For example, the English expression to sing to a different tune, which means to reverse one's views or to change one's mind. Similarly, in Chinese, chang-dui-tai-xi, the back translation is "to sing different tunes" but with a different meaning it means "to sing a duet".

3) An idiom may be used in the source text (ST) in both its literal and idiomatic senses at the same time. Unless the TL idiom corresponds to the source language (SL) idiom both in form and in meaning, the play of meanings cannot be successfully reproduced in the target text (TT). For example, the English expression pokes his nose into can be used both literally and idiomatically.

4) The very convention of using idioms in written discourse, the context in which they can be used, and their frequency of use may be different in the SL and in the TL. Baker states that "using idioms in English is thus very much a matter of style. Languages such as Arabic and Chinese, which draw a sharp distinction between written and spoken discourse and where the written mode is associated with a high level of formality tend, on the whole, to avoid using idioms in written texts" (2011, p. 75).

Baker (2011) discusses the Category 2 that was missed by Gläser (1984) and Awwad (1990), in which expressions use the same or similar images but with different connotations. This category will be adapted in this study's classification along with other classifications from Awwad's categories but here the terms will be different, they will be based on the variables of image and meaning to make it easier to comprehend. Following the literature review and after analysing the responses from the 35 participants (cf. Aldhahi et al., 2016), the researchers present five classifications as the most comprehensive approach covering all aspects mentioned by previous authors based on image and meaning:

1) Same image-same meaning (SaI-SM), i.e., the word image is exactly the same in both languages and refers to the same meaning (see example 1, Table 3).

2) Similar image-same meaning (SiI-SM), i.e., the word image is almost the same in both languages and it refers to the same meaning. Thus, if there is an expression that uses five words, four words are the same and one is different (see example 2, Table 3).

3) Different image-same meaning (DI-SM), i.e., both languages have produced the same idiomatic senses but by using different words (see example 3 , Table 3).

4) Same/similar image - different meaning ( $\mathrm{SaI} / \mathrm{SiL}-\mathrm{DM})$, where the expressions in both languages use the same or similar words in literal or idiomatic senses but have different meanings (see example 4, Table 3 ). 
5) No equivalent (NOEQ), where the meaning and/or image have no counterparts in the L2 (see example 5, Table 3).

Table 3. The five classifications

\begin{tabular}{|c|c|c|c|c|}
\hline ID & Classifications & $\begin{array}{l}\text { English } \\
\text { expression }\end{array}$ & Arabic equivalence & Back translation \\
\hline 1 & $\begin{array}{l}\text { Same image-Same } \\
\text { meaning }\end{array}$ & Crocodile tears & دموع التماسيح & Crocodile tears \\
\hline 2 & $\begin{array}{l}\text { Similar image-Same } \\
\text { meaning }\end{array}$ & $\begin{array}{l}\text { Apple of her } \\
\text { father's eye }\end{array}$ & قرت عين أبيها & Joy of her father's eye \\
\hline 3 & Different image & As wise as an owl & حكيم كلقمان & $\begin{array}{l}\text { As wise as Loqman (a man } \\
\text { famous for his wisdom) }\end{array}$ \\
\hline 4 & $\begin{array}{l}\text { Same } / \text { Similar } \\
\text { image-Different } \\
\text { meaning }\end{array}$ & $\begin{array}{l}\text { You're } \\
\text { my/mommy's little } \\
\text { monkey } \\
\text { (positive meaning) }\end{array}$ & كالقرد & $\begin{array}{l}\text { Like a monkey } \\
\text { (negative meaning) }\end{array}$ \\
\hline 5 & $\begin{array}{l}\text { No equivalent in image } \\
\text { or in meaning }\end{array}$ & Golf widow & 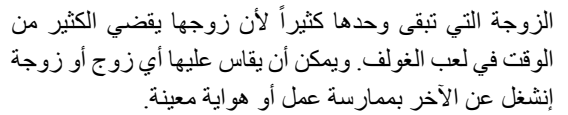 & $\begin{array}{l}\text { The wife who stays alone } \\
\text { because her husband spends a } \\
\text { lot of time playing golf. }\end{array}$ \\
\hline
\end{tabular}

Table 3 presents examples of each category in English CBI and their equivalent in Arabic CBI with back translations for the Arabic CBIs. This will facilitate discussion of each example with a native speaker in English and Arabic to give them the closest equivalent and enable classification of each example. Analysing each type of challenge in translating the CBIs between Arabic and English and the best solutions per each type of CBI will be presented in sections 5.1., 5.2, 5.3, 5.4 and 5.5. Finally, a discussion on the results and limitations of the study will be addressed in section 6 .

The translation solutions drawn upon in this study mainly relate to cultural correspondence. This type of cover is what Vinay and Darbelnet term equivalence and adaptation (1995, p. 32). Equivalence has two dimensions: natural equivalence by replacing the expression $\mathrm{A}$ with the expression $\mathrm{B}$ and, at the same time, expression $\mathrm{B}$ can be replaced exactly with expression A (Pym, 2010, p. 2); and directional equivalence by using different typology of translation solutions that are addressed in Table 1 such as resegmentation, perspective changes and density change; "the translator has active choices to make and there is no guarantee of exact return" (Pym, 2010, p. 2). In general, the process of translation is usually affected by the translator's ideology and how ideology can affect the selection of words in the target text (Schäffner, 2003; Tymoczko, 2003).

\subsection{SAME Image - SAME Meaning}

This class can be considered the easiest class among the five categories if the translator is competent in his/her native language. In this case, translators can retrieve more quickly the figurative meaning in the L2 because they can recognise the expressions when they see them. Therefore, they can bypass the literal meaning as explained in the figurative first hypothesis that explained the native speakers' retrieval of figurative language (Gibbs, 1980); this can also be used for any expression in the target language that uses the same image and same meaning. As explained by Wray (2002), CBIs are processed faster than the literal meaning of expressions. For example, the proverb at the tip of one's tongue corresponds to the Arabic (على طرف لسانه), the back translation being at the tip of one's tongue. The best solution uses the natural equivalence as shown in Table 4. 
Table 4. SAME image-SAME meaning

\begin{tabular}{|c|c|c|c|}
\hline ID & Expression (SL) & Expression (TL) & Back Translation \\
\hline \multicolumn{4}{|c|}{ Idioms/Idiomatic expressions } \\
\hline 1 & Pull the rug out from under (a person) & بسحب البساط من تحته & Pull the rug out from under (a person) \\
\hline 2 & $\begin{array}{l}\text { Wash one's hands of (someone or } \\
\text { something) }\end{array}$ & 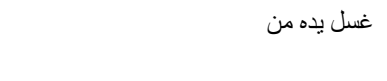 & Wash one's hands of (someone or something) \\
\hline 3 & Shed crocodile tears & 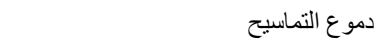 & Shed crocodile tears \\
\hline 4 & At the tip of one's tongue & على طرف لسانه & At the tip of his tongue \\
\hline \multicolumn{4}{|c|}{ Proverbs } \\
\hline 5 & $\begin{array}{l}\text { People who live in glass houses should not } \\
\text { throw stones }\end{array}$ & بالحجارة بيته من زجاج لا يرشق الناس & $\begin{array}{l}\text { People who live in glass houses should not throw } \\
\text { stones }\end{array}$ \\
\hline 6 & Speech is silver, but silence is golden & إذا كان الكلام من فضة فالسكوت من ذهب & Speech is silver, but silence is golden \\
\hline 7 & Actions speak louder than words & الأعمال أعلى صوتاً من الأقو ال & Actions speak louder than words \\
\hline 8 & A drowning man will clutch at a straw & الغريق بتعلق بقشة & A drowning man will catch at a straw \\
\hline \multicolumn{4}{|c|}{ Similes } \\
\hline 9 & As light as a feather & 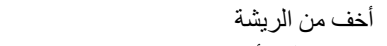 & As light as a feather \\
\hline 10 & As brave as a lion & 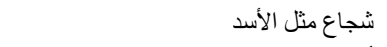 & As brave as a lion \\
\hline 11 & As proud as a peacock & أز هى من طاووس & As proud as a peacock \\
\hline 12 & As different as night and day & بأختلاف الليل و النهار & They are as different as night and day \\
\hline
\end{tabular}

In Table 4, all three classes of CBI have used an identical idiom for the translation, as the image used and the meaning is the same which makes this category the least challenging among the five categories.

\subsection{SIMILAR Image—SAME Meaning}

Similar to the previous category, this category is straightforward as the image and the meaning are familiar. The translators can retrieve the CBI faster in the L2 since they can recognise the expressions once they read them or hear them so they can avoid the literal meaning using the figurative first theory (Gibbs, 1980) and Wray's formulaic language. However, it is more challenging than the first class as the translator has to pay special attention to the differences between the two expressions. Similar to the previous category, the best solution is natural equivalence as illustrated in Table 5.

Table 5. SIMILAR image-SAME meaning

\begin{tabular}{|c|c|c|c|}
\hline ID & English CBI & Arabic CBI & Back Translation \\
\hline \multicolumn{4}{|c|}{ Idioms/Idiomatic expressions } \\
\hline 1 & Waste one's breath & يضيع وقته & Waste one's time \\
\hline 2 & By heart & عن ظهر قلب & By back of the heart \\
\hline 3 & She was the apple of her father's eye & كانت قرت عين ابيها & She was the joy of her father's eye \\
\hline 4 & Jack of all trades and master of none & سبع صنائع و البخت ضائع & $(\mathrm{He})$ of seven trades and fortune is lost \\
\hline \multicolumn{4}{|c|}{ Proverbs } \\
\hline 5 & A friend in need is a friend indeed & الصديق وقت الضيق الصيق & The friend is in need \\
\hline 6 & An English man's home is his castle & جنة الرجل بيته & A man's paradise is his house \\
\hline 7 & A bird in the hand is worth two in the bush & عصفور في اليد خير من عشرة على الشجرة. & A bird in the hand is worth ten in the bush \\
\hline 8 & Too many cooks spoil the broth & كثرة الطباخين تفسد الطبخة & Too many cooks spoil the food \\
\hline \multicolumn{4}{|c|}{ Similes } \\
\hline 9 & As quick as a flash & 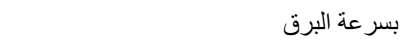 & As quick as lightning \\
\hline 10 & Be as busy as a bee & كخلية النحل & Be as busy as a bee cell \\
\hline 11 & Like father like son & الابن سرٌ أبيه & The son is his father's secret \\
\hline 12 & Like cats and dogs & مثل القطو الفار & Like cat and mouse \\
\hline
\end{tabular}

In Table 5, the 12 examples have similar images and the meanings are the same. For example, the English idiom by heart corresponds to the Arabic (عن ظهر قلب), the back translation of which is by back of the heart. Thus, both expressions correspond to each other but the Arabic CBI has the additional word, back.

\subsection{DIFFERENT Image — SAME Meaning}

In this category, both expressions have the same meaning, but use different images. For example, the English simile like a snail corresponds to the Arabic (بطيء مثل السلحفاة) and the back translation is "like a turtle". In this class, the challenge is greater as the translator has to find a completely different expression that has the same 
meaning. The first problem that might face the translator is to recognise the expression. Similes can be recognised easily by looking to the syntactic structure used (i.e., as...as, or like...); idioms can also be easily recognised, especially when they are not logical and grammatically not correct. With regard to proverbs, they can be more challenging due to the fact that they are generally well constructed grammatically and the meanings of their individual component words are logical. However, translators can recognise proverbs by looking to the moral teaching they generally convey.

Strategies used by translators such as the simultaneous processing and literal first hypotheses can identify the figurative expression which is the most important step to translate CBIs. It is then the translator's responsibility to provide the meaning by finding an effective equivalent. The best typology (cruise mode) seems to be cultural correspondence or describing the meaning by adapting and/or paraphrasing. This is illustrated in Table 6 .

Table 6. DIFFERENT image-SAME meaning

\begin{tabular}{|c|c|c|c|}
\hline ID & English CBI & Arabic CBI & Back Translation \\
\hline \multicolumn{4}{|c|}{ Idioms/Idiomatic expressions } \\
\hline 1 & $\begin{array}{l}\text { You can lead a horse to water but you } \\
\text { can't make it drink }\end{array}$ & و المبين على الرسول إلا البلاغ & $\begin{array}{l}\text { There is not upon the Messenger except the [responsibility } \\
\text { for] clear notification }\end{array}$ \\
\hline 2 & In the nick of time & 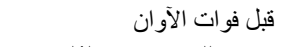 & Before it's too late \\
\hline 3 & Love me, love my dog & إكر اما للورد يشرب العُليق & $\begin{array}{l}\text { For the sake of the rose (a lover), one would even drink } \\
\text { blackberries }\end{array}$ \\
\hline 4 & Hell hath no fury (like a woman scorned) & 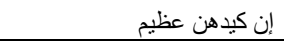 & Their (fem.) scheme is great \\
\hline \multicolumn{4}{|c|}{ Proverbs } \\
\hline 5 & $\begin{array}{l}\text { Lock the stable door after the horse has } \\
\text { bolted }\end{array}$ & إذا فات الفوت ما ينفع الصوت & If you missed the passing no benefit of the sound (voice). \\
\hline 6 & A leopard never changes its spots & من شب على شيء شاب عليه & $\begin{array}{l}\text { If a young person grows up doing something } \mathrm{s} / \mathrm{he} \text { will grow } \\
\text { older doing the same. }\end{array}$ \\
\hline 7 & The early bird catches the worm & "بورك لأمني في بكور ها"، & Honouring my nation in their earliness \\
\hline 8 & $\begin{array}{l}\text { Never trouble trouble till trouble troubles } \\
\text { you }\end{array}$ & دع العور اء تخطاك & Let the bad act or saying pass you \\
\hline \multicolumn{4}{|c|}{ Similes } \\
\hline 9 & As wise as an owl & حكيم كلقمان & As wise as Loqman (a man famous for his wisdom) \\
\hline 10 & Like a snail & بطيء مثل السلحفاة & Like a turtle \\
\hline 11 & As tough as nails & مثل الحجر قاسي & As tough as a stone \\
\hline 12 & As different as chalk and cheese & باختلاف الليل و النهار & As different as night and day \\
\hline
\end{tabular}

\subsection{SAME/SIMILAR Image—DIFFERENT Meaning}

In this category, both expressions have the same or similar images, but the meaning connotation with the words is different. For example, the English idiom when in Rome do as the Romans do is one of the expressions that present a considerable challenge as the survey found that many translators translated it into the Arabic CBI ( (مكة أدرى بشعابها passes) as shown in Table 7. The meaning here is to question the specialist in the area on the basis of inadequate knowledge, whereas the meaning of the English idiom is to behave as the locals do. This is a totally different meaning since the English CBI means to act and adapt to the same behaviour as the people around (to adapt to the customs and traditions of the places you visit). The cultural correspondence phrase in Arabic is ( إذا كنت في قو من whose back translation is If you are within a people milked on their bowl. The problem with this expression is that it is not familiar or frequently used in contrast with the people of Mecca know their Mecca routes through mountain passes as explained by Swinney and Cutler (1979) based on simultaneous processing hypothesis that the idiomatic meaning must have an advantage in terms of processing speed that hinders the literal meaning.

It is also based on the figurative first hypothesis (Gibbs, 1980) where native speakers rarely attempt a literal reading of the CBI because they process the figurative meaning easily when they see it and therefore bypass the literal meaning. As a result, if there is no cultural correspondence or if it is not familiar in the L1, the best strategy to use is directional equivalence. The challenge in this class is that translators might think it is the first or the second class as $\mathrm{s} / \mathrm{he}$ is familiar with the figurative expression (see Table 3 and Table 4). The translation solution suggested in this case is resegmentation (cruise mode). Pym (2017, p. 2) defines this typology as "the splitting or joining of sentences; re-paragraphing; generally changing the order of text parts at sentence level or 
above". Calque is not appropriate as it can lead to misunderstandings; for example, as strong as an ox, if the translators keep the same image it will be unacceptable as it is already used in the target language but with a different meaning. Thus, if the translator decides to borrow the English CBI as strong as an ox, s/he will make a mistake as the expression already exists in Arabic but with a negative meaning, not strong but rather stupid. Thus, the best procedure is to give more explanation by using paraphrase (footnote or gloss) and descriptive equivalent.

Table 7. SAME/SIMILAR image_-DIFFERENT meaning

\begin{tabular}{|c|c|c|c|c|}
\hline ID & English CBI & Arabic CBI & Back-Translation & Directional Equivalence \\
\hline \multicolumn{5}{|c|}{ Idioms/Idiomatic expressions } \\
\hline 1 & $\begin{array}{l}\text { Three sheets to } \\
\text { the wind }\end{array}$ & ذهب مع الريح & Went with the wind & مخمور جداً/ سكران \\
\hline 2 & $\begin{array}{l}\text { Bury one's head } \\
\text { in the sand }\end{array}$ & يدفن ر أسه بالتر اب & $\begin{array}{l}\text { Bury his head in the sand (because of } \\
\text { shame) }\end{array}$ & $\begin{array}{l}\text { لا تختبئ عن القيام بما يلزم } \\
\text { Said to someone who did something shameful to } \\
\text { him/her }\end{array}$ \\
\hline 3 & $\begin{array}{l}\text { On the horns of a } \\
\text { dilemma }\end{array}$ & على كف عفريت & On the balm of devil & In a very dangerous situation \\
\hline \multirow[t]{2}{*}{4} & $\begin{array}{l}\text { Have a tiger by } \\
\text { the tail }\end{array}$ & جاب الذئب من ذيله & Have a wolf by the tail & ترجنهال حين التورط بشيء مشكلة قوي ويحتب حلها أن يكون خطر. ويمكن \\
\hline & & & & Bring the news \\
\hline \multicolumn{5}{|c|}{ Proverbs } \\
\hline 5 & $\begin{array}{l}A \text { bad excuse is } \\
\text { better than none }\end{array}$ & عذر أقبح من ذنب & The excuse is worse than the guilt & تمامأ. \\
\hline \multirow[t]{2}{*}{6} & $\begin{array}{l}\text { When in Rome do } \\
\text { as the Romans do }\end{array}$ & بشعابها & $\begin{array}{l}\text { The people of Mecca know their Mecca } \\
\text { routes (i.e. they know where the mountain } \\
\text { passes are) }\end{array}$ & 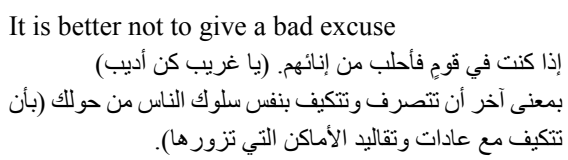 \\
\hline & & & & $\begin{array}{l}\text { In other words, to act and adopt the same } \\
\text { behaviour of the people around you (to adapt to } \\
\text { the customs of the places you visit). }\end{array}$ \\
\hline 7 & $\begin{array}{l}\text { Absence makes } \\
\text { the heart grow } \\
\text { fonder }\end{array}$ & البعن عن القلب العين بعيد & Far from the eye, far from the heart & $\begin{array}{l}\text { ككس المعنى: البعد يزيد الحب ولو عا /ابعد حبك يزيد } \\
\text { Said as an excuse to someone who has not stayed } \\
\text { long and not been in touch. }\end{array}$ \\
\hline 8 & $\begin{array}{l}\text { The tail wagging } \\
\text { the dog }\end{array}$ & ما رجعرف راسه من أعوج & $\begin{array}{l}\text { You don't know his head from his tail/ } \\
\text { The dog's tail is always askew }\end{array}$ & $\begin{array}{l}\text { عندما يسيطر الأمر الصغير على الكبير } \\
\text { Said when the little one controls the big one }\end{array}$ \\
\hline \multicolumn{5}{|c|}{ Similes } \\
\hline 9 & $\begin{array}{l}\text { As tall as a } \\
\text { giraffe }\end{array}$ & طويل كالزر افة & Tall like a giraffe (negative connotation) & طويل (تشبيه إيجابي) \\
\hline 10 & $\begin{array}{l}\text { As strong as an } \\
\text { ox }\end{array}$ & (تشبيه سلبي) & Strong like an ox (negative connotation) & قوي (تشبيه إيجابي) \\
\hline 11 & $\begin{array}{l}\text { As funny as a } \\
\text { barrel of monkeys }\end{array}$ & مثل القرد (تثبيه & $\begin{array}{l}\text { Funny like a monkey (negative } \\
\text { connotation) }\end{array}$ & مضحك جداً (تثبيه إيجابي) \\
\hline 12 & As the crow flies & 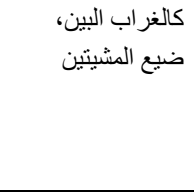 & $\begin{array}{l}\text { Like a crow, s/he lost the two walks } \\
\text { (negative connotation) }\end{array}$ & 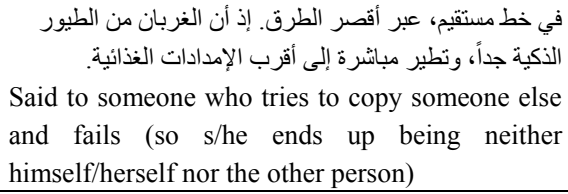 \\
\hline
\end{tabular}

\subsection{No Equivalent in Image or in Meaning}

This category shows the cultural untranslatability which poses the highest challenge in translation because of the absence of a relevant equivalent in the TL as illustrated in Table 8. Olwi (unpublished thesis) proposed that this category represents the highest level of linguistic sensitivity. If any word is not acceptable in the target culture, it can open the door for CBIs that do not exist in the target culture (Ghazala, 2014). For instance, the Arabic CBI has been rendered into the English CBI as "Ka'ba" while Ghazala suggests translating it as "the Holy House of God" supplemented with a further comment: "at Makkah, from Muslims". According to cruise mode this is "density change". Another example, cricket, can be rendered (لعبة الكركيت/رياضة الكريكت) whose back translation is "cricket sport/game". Generally, Ghazala in these examples uses adoption and gives short and 
sometimes long paraphrases in order to open up to new cultures.

On the other hand, he points out that some of these English CBIs have a "unique case" where they should be copying the sounds such as (حج). Although this word has an equivalent in TC, which is pilgrimage, it is better to render it into "Hajj" as this word refers to a specific place of worship for Muslims in the Holy mosque in Makkah. This typology is referred to as "copying words" according to Pym (2017). The challenge here can be how to recognise the figurative expression as sometimes a literal meaning can be accessed first, such as Beware of the Greeks bearing gifts. According to the literal first hypothesis, the literal meaning is processed more quickly than an idiomatic meaning if the figurative meaning does not exist in the L1. However, translators can learn other procedures to identify first the figurative expressions and then think of the best way to render them.

As explained in section 2, translators can identify the English CBIs in different ways. For the three categories studied in this paper (idioms/idiomatic expressions, similes and proverbs), translators can look to the syntactic structure used "as...as .../ like..." (to recognise an expression as a simile), grammatically incorrect and/or semantically illogical (to recognise idioms and idiomatic expressions) and/or look for moral values and a story behind the expression (to recognise it as a proverb). This is further exemplified in Table 8.

Table 8. NO EQUIVALENT in image or in meaning

\begin{tabular}{|c|c|c|c|}
\hline ID & Expression & Literal Meaning & Directional Equivalence \\
\hline 1 & Golf widow & (absence of a relevant & 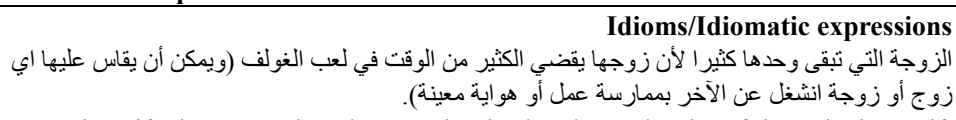 \\
\hline 2 & $\begin{array}{l}\text { To get in } \\
\text { Dutch with } \\
\text { someone }\end{array}$ & 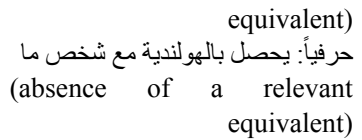 & 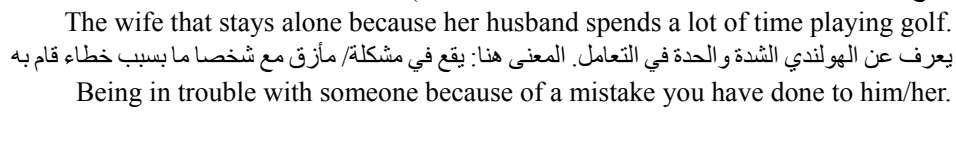 \\
\hline 3 & و لو لو ناقة لي فيها & $\begin{array}{l}\text { Neither a female nor a male } \\
\text { camel }\end{array}$ & This matter doesn't concern me! \\
\hline 4 & أبيصامة من زرقاء & $\begin{array}{l}\text { More far seeing than } \\
\text { blue-eyed (Zrqa' al-Yamama) }\end{array}$ & $\begin{array}{l}\text { The Arab's long-sighted power which means "far seeing" } \\
\text { A blue-eyed woman with exceptional intuition. Zrqa's tribe relied on her powers in } \\
\text { detecting enemies and defending their land, as she was believed to have the ability } \\
\text { to see riders from three days' distance away. }\end{array}$ \\
\hline & & & \\
\hline 5 & $\begin{array}{l}\text { Beware of } \\
\text { the Greeks } \\
\text { bearing gifts }\end{array}$ & $\begin{array}{l}\text { كن حذر من الهدايا التي يحملها الإغريق } \\
\text { (absence of a relevant } \\
\text { equivalent) }\end{array}$ & $\begin{array}{l}\text { قصة تعود لحصان طرو ادة. ويقصد بها عدم الوثوق بالأعداء حين قيامهم بعمل لطيف تجاهك لجن for you } \\
\text { Do not trust your enemies even if they do something nice for }\end{array}$ \\
\hline 6 & $\begin{array}{l}\text { Too many } \\
\text { chiefs and } \\
\text { not enough } \\
\text { Indians }\end{array}$ & 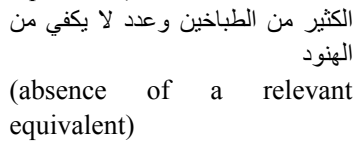 & تقال عندما يكثر عدد القياديين و عدد العاملين قليل \\
\hline 7 & حذام القول ما قالت & $\begin{array}{l}\text { The saying is what Hutham (a } \\
\text { woman's name) said }\end{array}$ & $\begin{array}{l}\text { This is what Hutham said } \\
\text { (Said when there is sincere and authentic talk) }\end{array}$ \\
\hline 8 & أردى الله امبئ & $\begin{array}{l}\text { Womb of God who gifted us } \\
\text { our mistakes. }\end{array}$ & $\begin{array}{l}\text { To ask someone to tell you truly your mistakes and show that you would be pleased } \\
\text { if s/he does so. }\end{array}$ \\
\hline \multicolumn{4}{|c|}{ Similes } \\
\hline 9 & $\begin{array}{l}\text { As cool as a } \\
\text { cucumber }\end{array}$ & $\begin{array}{l}\text { رائق كالخيار } \\
\text { (absence of a relevant } \\
\text { equivalent) }\end{array}$ & الصورة غير مفهومه. ويمكن ترجمنها الى: رائق مرتاح جداً \\
\hline 10 & $\begin{array}{l}\text { As nutty as a } \\
\text { fruitcake }\end{array}$ & \begin{tabular}{lll} 
& \multicolumn{3}{c}{ مز عج كما كعكة الفو اكة } \\
(absence of a & relevant \\
equivalent) & &
\end{tabular} & As nutty as a fruitcake \\
\hline 11 & كشعرة معاوية & As Mu'awaiah's single hair. & $\begin{array}{l}\text { An old simile that was said when Mu'awaiah (Arabic leader) was asked about how } \\
\text { he could manage his relationship with his people in a very difficult time. He said } \\
\text { like a single hair, if the hair is tightened, he loosens it, if it is too loose, he tightens } \\
\text { it, all in the interests of flexibility. Meaning: being balanced between flexibility and } \\
\text { strength. }\end{array}$ \\
\hline 12 & كمسمار جحا & Like Juha's nail & $\begin{array}{l}\text { A popular folklore story that Juha sold his house except one nail. In the sale } \\
\text { contract, he stipulated that he can do whatever he wanted with the nail. Later, he } \\
\text { came back many times at inconvenient times with a hammer in his hand and bangs } \\
\text { the nail. Meaning: something becomes no more than a vacuous excuse. }\end{array}$ \\
\hline
\end{tabular}


The translator has to be a sophisticated reader of the source language and culture, as many of these expressions refer to a deep understanding of target culture's beliefs, history and values. Then, translators should take into account the purpose of the translation (Skopos theory, Reiss \& Vermeer, 1984). Thus, regarding the English exclamation Christ! The image and the meaning do not exist in Muslim culture and would not be acceptable as they are not part of Muslim beliefs. Thus, the translator in this case has to understand the purpose of this expression (Skopos), and when and how it is used in order to be able to give the directional equivalence. This English CBI is an oath used to express irritation, dismay, or surprise; consequently, the translator can replace it by other oaths in Arabic CBI such as (سبحان الذ) which corresponds in English to Glory to Allah/God. This is what is called 'perspective change' typology according to Pym's cruise mode. So, if the meaning is culturally unacceptable, the translator can paraphrase (footnote or gloss), or use a descriptive equivalent in the footnote or gloss with/without calque. But if the meaning is inappropriate, then the translator can simply use the omission procedure, which goes in line with 'text tailoring' another type of translation solution (Pym, 2017).

However, it is sometimes impossible to rely exclusively on the omission procedure if the word is essential in the text. At the same time, there are some CBIs that have proposed a clash of cultures in translation. A recent example illustrates the adherence of this case; a political meeting was held between the president of Turkey, Tayyip Erdogan, and the German Chancellor, Angela Merkel, on the $3^{\text {rd }}$ of February, 2017. She said: "We spoke in detail about [...] the questions of the fight against Islamist terrorism, against every form of terrorism, also the terrorism of the PKK" (cf. Express, 2017). She used phrases including Islamist terrorism (a common English CBI used after the events of September 11 by George W. Bush) which left Turkey's president furious. The president said that "This expression "Islamist terror" seriously saddens us Muslims... Such an expression is not correct because Islam and terror cannot be associated. The meaning of Islam is peace... As a Muslim president, personally I cannot accept that" (O'Brien 2017). While it might have been tempting for the translator to remove offensive content from the original, translators should always aim to render the source text faithfully, regardless of their own views and emotions about the content of the original. Therefore, the unfortunate term used by Merkel must stand. However, this example highlights the importance of translating cultural content appropriately by design rather than by accident or by force of habit.

Under different circumstances and if required in a specific context, the offensive content could have been avoided by rendering it as Daesh (Arabic CBI), another term for Islamist terror, Islamic radical and ISIS (the Islamic State of Iraq and Syria). In any case, this example shows to what extent there can be a clash between two cultures which have different identities, beliefs and values. It can be a significant challenge for translators to translate the counter opinions that are expressed by different orientations about major and crucial matters in the world. Ghazala claimed in this regard:

"Our 21st Century is the century of globalization, stunning electronics, technology of communications, media and open-mindedness with the other. It is the age of bringing the world closer and making it smaller. Yet, at the same time, it is the age of individualism, localism, nationalism, national pride, global anti-culture, and adherence to one's own culture, character, tradition, conventions, customs, beliefs and values of all types" (2014).

Another typology of translation solutions addressed by Pym is 'compensation' (see table 1). This can be explained by the expression, golf widow, which has no equivalence in Arabic. However, the sense can be translated into Arabic with different textual position such as (الزَوجة المُهُمَلَة (2014), the back translation is 'neglected wife'. Ghazala (2014) also suggests that adding at least a short comment after translating the offensive English CBIs, such as ("sic" (وهذا غير صحيح "not true, might be the appropriate rendering in some contexts. Generally, the six typologies of translation solutions can be suggested for this category of challenge: perspective change, density change, compensation, text tailoring, copying words and structure.

\section{Limitations of the Study}

Most research on the translation of figurative expressions has focused on the most challenging area in translation expressions by which non-equivalence in the L1 and/or the solutions to overcome this particular area of challenge; their limitation is that they do not address all the levels of challenge such as the expressions that have the same image but that are perceived differently, nor the similarities between the image and meaning between the two cultures involved. It is very important to have a comprehensive approach as a guide for learners. The results of this study were based on a select group of works: Awwad (1990), who addresses four types of similarities and differences in idioms and idiomatic expressions between English and (Jordanian) Arabic; Baker (2011), who suggests four categories, and Gläser (1984) who proposes three categories of idioms. Based on this literature and also based upon the results of previous study (Aldhahi et al., 2016) on types of challenges face 
translators, this study proposes five categories of translation challenges.

Most of these studies overlap in their coverage of idioms, proverbs, idiomatic expressions, metaphors and similes. Likewise, the authors have not found any study in Arabic focusing exclusively on the translation of similes except one study by Ghazala (2007). Most of the studies deal with idioms or other idiomatic expressions and consider similes as a related type.

This research may have been constrained by two aspects. First, the data collection was extensive to almost all types of CBIs, but due to space limitations, the authors presented only three types of CBIs: proverbs, idioms and similes. Second, the classifications in this study were mainly based on classifications formulated by Awwad (1990) and others but using different terms that are easy to learn by trainee translators; a new classification was added that distinguishes this study from other studies. These classifications have been carefully selected but not yet validated by professionals in the field of translation which will be the authors' aim for future studies.

\section{Conclusions}

At the outset of the current study, it was emphasised that language is conditioned by culture. Thus, translation should be considered to be equally informed by language and culture in the process of cross-cultural communication. The result of this paper shows five types of similarities and differences between the two languages and cultures involved by analysing the image and the meaning and providing the optimum translation strategy and procedure to follow.

Arabic professional translators have to improve their cultural knowledge of CBIs in their different aspects (i.e., political, religious, symbolic, historical and so on) in both Arabic and English in order to achieve more effective equivalence by considering the similarities and differences between both languages and cultures involved. Also, the results of a previous study (Aldhahi et al., 2016) highlight the inadequate translation procedures used in the translation of CBIs. Thus, in this paper, the researchers have aimed to establish the challenges posed for Arab professional translators in translating CBIs between English and Arabic; the challenge is first to recognise the English CBI and then find the best solution for its translation.

In this respect, translators can identify the English CBIs (idiom and idiomatic expression, proverbs and similes in this study) in different ways, e.g. the syntactic structure, grammatical construction and whether a particular expression carries a moral teaching. After studying the literature of other authors in this regard and drawing on material presented in a previous study (Aldhahi et al., 2016), the results show five categories on the basis of image and meaning and then suggest the best solution for overcoming these cultural challenges by category (see Table 9).

Table 9. Challenges and solutions

\begin{tabular}{|c|c|c|}
\hline ID & Five level of challenges & Solution (using Pym's cruise mode) \\
\hline 1 & $\begin{array}{l}\text { Same image-Same meaning } \\
\text { (Table 5) }\end{array}$ & natural equivalent \\
\hline 2 & $\begin{array}{l}\text { Similar image- }- \text { Same meaning } \\
\text { (Table 6) }\end{array}$ & natural equivalent \\
\hline 3 & $\begin{array}{l}\text { Different image — Same meaning } \\
\text { (Table 4) }\end{array}$ & cultural correspondence \\
\hline 4 & $\begin{array}{l}\text { Same/Similar } \quad \text { image }- \text { Different } \\
\text { meaning } \\
\text { (Table 7) }\end{array}$ & resegmentation \\
\hline 5 & $\begin{array}{l}\text { No equivalent in image or in meaning } \\
\text { (Table 8) }\end{array}$ & $\begin{array}{l}\text { perspective changes, density change, compensation text tailoring, copying words and } \\
\text { structure }\end{array}$ \\
\hline
\end{tabular}

Possible natural equivalent procedure is suggested for the first two categories of challenges (same image- same meaning, similar image — same meaning and different image — same meaning). Also, translators recommended to use cultural correspondence for the third category (Different image - Same meaning).

In the fourth category of challenge (same/similar image — different meaning),both figurative expressions exist in both cultures, but the connection is different, it is most important for translators to process the literal meaning first, then produce the figurative meaning without using the figurative expression in the target culture. Therefore, resegmentation seems an appropriate typology for this challenge.

For the last category (no equivalent in image or in meaning), translators can open up to a new culture and adapt 
the CBI to the target culture and/or use copying words, copying structure, density change and compensation (cruise mode). Also in this category, a CBI can cause a clash of cultures in translation if it is considered a strong $C B I$. Thus, the translator can use perspective changes and text tailoring. Overall, the results suggest that there is an urgent need to increase trainee translators' overall cultural competence by increasing their English and Arabic vocabularies (cf. Al-Ghussain, 2013). Once trainees become professionals, they will need a comprehensive knowledge of translation challenges in translating CBIs which will continue to help them find solutions to overcome these challenges. Therefore, further research to support the findings of the current study is needed, in terms of presenting these five challenges to Arabic translators to examine the challenges and provide a valid and reliable test for cultural content in translation studies.

\section{Acknowledgments}

We would like to express our appreciation to the Saudi Culture Bureau in the UK and to the Ministry of Education for providing the funding for this research and also to Swansea University for all their support.

\section{References}

Aldhahi, M. et al. (2016). Investigating the Relationship between Vocabulary Size and Cultural Competence in English-Arabic Translation. Conference paper at the 9th Annual International Conference on Languages and Linguistics, 4-7 July 2016, Athens, Greece. Retrieved Dec. 5, 2017 from https://goo.gl/GjRWHv

Al-Faifi, A. S. A. (2000). Teaching Translation at the Undergraduate Level in Saudi Arabia: The Case of Imam Muhammad lbn Saud Islamic University. (Doctoral dissertation). University of Edinburgh, Edinburgh. Retrieved Dec. 5, 2017 from file://tawe_dfs/Students/7/803807/Downloads/Al-Faifi2000\%20(1).pdf

Al-Ghussain, R. A. A. (2003). Areas of Cultural and Linguistic Difficulty in English-Arabic Translation. (Doctoral dissertation). Durham University, Durham. Retrieved Dec. 5, 2017 from http://etheses.dur.ac.uk/1416/

Alhaysony, M. H. (2017). Strategies and Difficulties of Understanding English Idioms: A Case Study of Saudi University EFL students. International Journal of English Linguistics, 7(3). http://dx.doi.org/10.5539/ijel.v7n3p70

Awwad, M. (1990). Equivalence and Translatability of English and Arabic Idioms. Papers and Studies in Contrastive Linguistics, 26(57), 58-67. Retrieved Dec. 5, 2017 from https://goo.gl/7Z8NkL

Baker, M. (2011). In Other Words: A Coursebook on Translation. London and New York: Routledge. http://dx.doi.org/10.1075/target.24.1.19che

Bobrow, S., \& Bell, S. (1973). On catching on to idiomatic expressions. Memory and Cognition, 1, 343-346. https://doi.org/10.3758/BF03198118

Duff, A. (1981). The Third Language. Recurrent Problems of Translation into English: It Ain't What You Do, It's The Way You Do It. Oxford and New York: Pergamon Press.

Ellis, N. C., \& Sinclair, S. G. (1996). Aptitude, Phonological Memory, and Second Language Proficiency in Nonnovice Adult Learners. Quarterly Journal of Experimental Psychology, 49, 234-250. https://doi.org/10.1017/S0142716409090109

Fernández-Parra, M. (2014). Formulaic Expressions in Computer-Assisted Translation: A Specialised Translation Approach. Saarbrücken: Scholars' Press.

Ghazala, H. (2007). Touching upon the Translation of the Style of Irony (English-Arabic). Babel, 53(1). https://doi.org/10.1075/babel.53.1.03gha

Ghazala, H. (2014). Translatability of Culture: Facts and Fallacies. Paper given at The 2nd International English and Translation Conference on Language: the Beacon of Culture and Thought, At Effat University, Jedda, KSA. Retrieved Dec. 5, 2017 from https://www.researchgate.net/publication/309313645_Translatability_of_Culture_Facts_and_Fallacies.

Gibbs, R. W. (1980). Spilling the Beans on Understanding and Memory for Idioms in Conversations. Memory and Cognition, 8, 148-164. https://doi.org/10.3758/BF03213418

Gläser, R. (1984). The Translation Aspect of Phraseological Units in English and German. Papers and Studies in Contrastive Linguistics Poznan, 18, 123-134. Retrieved Dec. 5, 2017 from https://goo.gl/38BmZZ

Jiang, N. (2000). Lexical Representation and Development in a Second Language. Applied Linguistics, 21(1), 47-77. https://doi.org/10.1093/applin/21.1.47 
Jiang, N. (2002). Form-meaning Mapping in Vocabulary Acquisition in a Second Language. Studies in Second Language Acquisition, 24(04), 617-637. https://doi.org/10.1017/S0272263102004047

Jiang, N. (2004). Semantic Transfer and Its Implications for Vocabulary Teaching in a Second Language. The Modern Language Journal, 88(3), 416-432. https://doi.org/10.1111/j.0026-7902.2004.00238.x

Karlsson, M. (2013). Quantitative and Qualitative Aspects of L1 (Swedish) and L2 (English) Idiom Comprehension. Studies in Second Language Learning and Teaching, 3(2), 293-319. https://doi.org/10.14746/ssllt.2013.3.2.7

Masrai, A., \& Milton, J. (2015). An Investigation of the Relationship between L1 Lexical Translation Equivalence and L2 Vocabulary Acquisition. International Journal of English Linguistics, 5(2). http://dx.doi.org/10.5539/ijel.v5n2p1

Newmark, P. (1991). About Translation. Clevedon. Philadelphia, Adelaide: Multilingual Matters.

O’Brien, Z. (2017). "The Meaning of Islam Is Peace" Erdogan FURIOUS with Merkel over "Islamist Terror" Comment. Express World News. Retrieved Dec. 5, 2017 from http://bit.ly/2k2Roc1

Olwi, A. (unpublished thesis). Subtitling the Taboo Is It a Taboo? Doctoral thesis, Swansea University.

Ortony, A. et al. (1978). Interpreting Metaphors and Idioms: Some Effects of Context on Comprehension. Journal of Verbal Learning and Verbal Behavior, 7, 465-477. https://doi.org/10.1016/S0022-5371(78)90283-9

Pym, A. (2010). Translation Theory today and Tomorrow: Responses to Equivalence. In L. N. Zybatow (Ed.), Translationswissenschaft: Stand und Perspektiven (pp. 1-14). Frankfurt: Peter Lang.

Pym, A. (2016). Translation Solutions for Many Languages: Histories of a Flawed Dream. London: Bloomsbury Publishing.

Pym, A. (2017). A Typology of Translation Solutions for Spanish-English (revised). Retrieved Dec. 5, 2017 from https://goo.gl/Dfhseq

Reiss, K., \& Vermeer, H. (1984). Groundwork for a General Theory of Translation. Tubingen: Niemeyer.

Schäffner, C. (2003). Third Ways and New Centres: Ideological Unity or Difference? In M. Calzada-Pérez (Ed.), Apropos of Ideology. Manchester: St. Jerome Publishing.

Swinney, D. A., \& Cutler, A. (1979). The Access and Processing of Idiomatic Expressions. Journal of Verbal Learning and Verbal Behavior, 18, 523-534. https://doi.org/10.1016/S0022-5371(79)90284-6

Tymoczko, M. (2003). Ideology and the Position of the Translator: In What Sense is a Translator "In Between"? In M. Calzada-Pérez (Ed.), Apropos of Ideology (pp. 181-201). Manchester: St. Jerome Publishing.

Vinay, J. P., \& Darbelnet, J. (1995). Comparative Stylistics of French and English: A Methodology for Translation. In J. C. Sager, \& M. J. Hamel (Trans. and Eds.). Amsterdam: John Benjamins. (Original work published 1958). https://doi.org/10.1075/btl.11

Wray, A. (2002). Formulaic Language and the Lexicon. Cambridge: Cambridge University Press. https://doi.org/10.1017/CBO9780511519772

\section{Copyrights}

Copyright for this article is retained by the author(s), with first publication rights granted to the journal.

This is an open-access article distributed under the terms and conditions of the Creative Commons Attribution license (http://creativecommons.org/licenses/by/4.0/). 